\title{
Parents in Pandemic: parents' perceptions of risks and psychological, relational, and pedagogical needs in childhood during the COVID-19 emergency in Italy.
}

Marianna Coppola, PhD Candidate

Department of Political and Communication Sciences, University of Salerno, Italy

Immacolata Senatore, PhD Candidate

Departement of Human, Philosophical and Educational Sciences, University of Salerno, Italy

Prof. Assoc. Giuseppe Masullo PhD

Director of International Lab for Innovative social research, University of Salerno, Italy

\section{Abstract}

The global spread of the SARS COV-2 virus and the related Coronavirus Disease-19 (Covid-19) has forced the entire planet to suddenly adopt important safety standards and reorganize social reality.

The present research investigates the perception of psychological, relational, and pedagogical risks and needs in the developmental age (3-18 years) by the parents of different Italian regions during the quarantine period. Specifically, we examined the opinions of parents regarding the rules of social distancing and the continuous and massive use of new technologies for distance learning (DL).

The results showed that Italian parents have two main concerns: on the one hand, the emergency in terms of health and health-related aspects; on the other, the teaching, training, and educational trajectories of children. They manifested mistrust and scepticism towards institutions and the school world, in terms of both management competence and structural and infrastructural capacity; aspects perceived as concerns also for Phase 2 and 3 of the epidemic curve.

Keywords: covid-19; global risks; developmental needs; health risks; digital divide.

\section{Introduction}

When, in 1977, the World Health Organization declared smallpox eradicated, the social perception of global risk in health changed radically, encouraging the illusion of being able to control every possible health emergency effectively and consistently. 
In 1985 the spread of a new, unknown, extremely lethal, and contagious zoonosis, the Acquired Immunodeficiency Syndrome (AIDS), challenged this new social perception of health risk. It created not only a mass psychosis but also major stigmatization of social categories that related to the pathology (e.g. drug addicts and homosexuals) (Sontang, 1989).

In the new century, the study of global health risk perception has enjoyed a growing interest in the scientific and academic community, reinforced by concerns about the spread of diseases such as Sars atypical pneumonia syndrome in 2003, H1N1 influenza in 2005, avian influenza in 2009 and Mers atypical pneumonia syndrome in 2012 (Pitrelli, Sturloni, 2007).

Although Sars and Mers had caused many deaths worldwide, they had again promoted the idea that the scientific community could contain health emergencies, which posed a threat only to specific cultures and geographical areas.

In January 2020, a new coronavirus (Sars-Cov2), belonging to the same virus strain as Sars, was identified in China.

The disease associated with the virus (classified with the acronym COVID-19) is characterized by high contagiousness and unpredictability in terms of both symptoms and side effects.

In a few weeks, Covid-19 has spread all over the world. On March 11, 2020, the World Health Organization declared a pandemic.

The national governments of the most affected countries have adopted extraordinary measures to prevent and contain the spread of the virus, introducing social distancing rules and shelter-in-place orders, effectively imposing a reorganization of the social reality in all areas of life.

The first weeks of the emergency (between the end of February and the beginning of March 2020) witnessed a massive scientific production in the medical and biological fields. Following the worldwide lockdown, the Human Sciences also began to question the importance of the event in the anthropological and sociological field, both in psychological and educational terms and the medium- and long-term repercussions on the well-being of individuals.

The Covid-19 pandemic has rekindled hot sociological issues, such as the perception of global risk, the importance of cultural and communicative processes in emergencies, the role of infodemics and media distortions. It has also highlighted the fragility of some organizational and social systems (e.g. health, school, and welfare systems) reinforcing and amplifying the psychological, social, and pedagogical concerns of individuals (Castells, 1996; Beck, 2008). 
During the lockdown, social, working, educational and relational life was suspended through extraordinary measures, strengthening online activities (such as smartworking and distance learning) and disrupting family dynamics on several fronts.

The first part of this work consists of a literature review. The analysis is threefold: the concept of global risk society and the main sociological theories on the subject; the perception of social risk and the analysis of needs in the evolutionary age, according to the theoretical model of bio-psycho-social well-being; inequalities and differences in training processes, focusing on the concept of digital divide in the pedagogical field.

The second section will analyse the perception of psychological, relational, and pedagogical needs and risks during the quarantine period by parents of children aged 3-18 years from different Italian regions. We will then offer some conclusive remarks and future research paths.

\section{The global Risk society}

The concept of risk is first elaborated before modernity in the insurance field. The main shipping companies identified, before each transoceanic crossing, the potential dangers, excluding human action from this analysis and considering only "external and natural" agents (Lupton, 2003).

With modern society and economic and industrial development, we witnessed a change in the definition of risk, which now includes also effects and factors related to human behaviour, in fact introducing the concept of probability of negative and positive outcomes to human action (ibid.).

The current concept of global risk is associated only with dimensions that refer to threat, danger, and the fight for survival.

It is crucial to distinguish between the concepts of danger and risk.

Danger is a characteristic of the object, situation or event that may cause harm to one or more people. Risk is the hazard associated with the probability of such an event occurring.

Ulrich Beck (2000) in the introduction to the Risk society, defined a direct and proportional correlation of global risk with the modernisation and wealth of the contemporary world.

This epistemological reflection is topical in terms of both risk perception and identification of the social and cultural spheres in which it is particularly important and evident. In contemporary society, individual action produces consequences that are reflected on the community, first in local terms (one's peripheral community, such as 
the family) and then in global terms (the most central and superstructural community, such as one's nation).

This societal structure determines complex interconnections between the processes of production of wealth and the psycho-physical and social well-being of individuals (ibid.).

The globalization of social systems extends to all communities not only the systems of production and exchange of wealth but also the interconnected risks, thus creating what Giddens (1994) defined as "the dark side of modernity". This generates "borderline" life situations, constantly on the threshold of a possible general and global risk that threatens the survival of hundreds of thousands of individuals worldwide.

The issue of social and global risk has enjoyed increasing attention in sociological analyses over the last thirty years, due to an increase in social and cultural phenomena linked to these constructs.

Slovic (2000) points out that, compared to other historical epochs, there is no increase in events or situations that heighten global risks, but there is greater awareness of it, amplified by the new and social media (Rogers, 2016).

One of the main theories on the perception of global risk is Mary Douglas's (1982) socio-cultural risk theory. The construction of perceptions, needs, concerns and responses to a situation of danger and social risk, the argument goes, is related to the social status and position occupied by the individual within the socio-cultural systems of belonging. According to Douglas, therefore, there is no univocal and universal process of social and global risk assessment and estimation. Rather, there is a cultural framework within which to identify the parameters and characteristic aspects of an emergency. Moreover, the approach holds morality and the value system within which are identified and sought, causes, responsibilities and resolutions to emergencies as crucial.

Within the strategies identifying threats and the processes to repair and restore the "social order", Douglas (1991) highlighted blaming, a process through which a threat to everyday life and the normal perception and action of the individual becomes (or is perceived) as concrete and probable (therefore it assumes the framework of danger). The stability of the group, undermined by danger, is restored by the identification of a "culprit", to direct attention and collective energies towards an enemy, an "external" agent who has caused fear, destabilization and suffering to the group.

Moralization and blaming processes are common to any situation of emergency or social risk, and are "necessary" to the masses from a psychological and social point of view, to loosen the psychological tension of individuals, thus lowering the social tension (ibid.). 
For example, 9/11 and the Isis kamikaze attacks in Europe in 2015-2016 created new forms of social stigmatization and blaming. Naturalized Islamic immigrants have been identified as potential enemies to public order and security, thus contributing to Islamophobia (Davids, 2020).

Moralization and blaming are also strongly present in the perception and analysis of social and global risk in the health sector.

For example, when AIDS spread throughout the world in the 1980s, homosexuals and drug addicts were stigmatised and the spread of the disease was blamed mainly on unregulated and immoral behaviour (Joffe, Bettega, 2003).

For zoonoses related to social and cultural practices (e.g. direct slaughter in the Eastern wet markets), there is significant moral censorship and stigmatisation by the West to what are considered uncivilized practices that undermine global security.

The perception and analysis of social risks in health are a major concern for the world's population, as health is one of the main areas of human life in terms of priorities and absolute good (Binotto, 2011).

In the first decade of the 2000s, there were several new health risks and related emergencies - a new respiratory disease caused by a zoonotic coronavirus, SARS, spread in the Far East in 2003; avian influenza in 2005, swine fever H1N1 in 2009, and MERS (of the same strain as SARS) in 2012.

All emergencies have been resolved with relatively effective containment, averting a global pandemic despite the numerous victims.

The recent COVID-19 pandemic has once again highlighted the scientific and sociological debate on the effects of globalization on the perception and spread of global risks. It imposed on all areas reflections and considerations to seek solutions on which to rebuild global security and confidence, undermined in recent months.

The perception of social risk and the analysis of psychological, social, and pedagogical needs in the developmental age.

The perception of social risk and the analysis of needs are the articulated result of a subjective, personal, and individualistic interpretation of reality in which different cognitive, psychological, and emotional factors play a central role (Joung, 2002).

We can identify several complex intrapsychic systems:

- Mental coherence understood as the internal structure of psychological phenomena such as psychic stability and the principle of self-preservation. 
- Cognitive flexibility understood as coping and problem-solving strategies adopted by the subject in the face of external problems and threats.

- The system of beliefs and values understood as the complex organization of mental representations, schemes, and cognitive scripts.

- Social norms and morals understood as the cognitive system of elaboration of social rules guiding individual action (ibid.).

Numerous studies have shown that when faced with a health hazard there is a perception of risk only when the threat approaches a proximal area, in terms of spatial or emotional proximity.

The psychological strategies that characterize the perception of social risk and the analysis of needs for oneself and one's loved ones can concern different spheres of individuals' lives and are influenced by specific factors, such as:

- Experience: individuals who have had direct experience with mental construction and risk scripting have a greater predisposition to carry out a holistic and detailed analysis of risks and needs, as there is a historical and semantic memory of risk in the subjects. Individuals or populations with greater expertise in threats and dangers implement coping and problem-solving strategies earlier than others, also acting as pathfinders or pioneers in general emergency resolution.

- Evolution: risk takes on a different meaning depending on the age of the individual. Adolescents and young adults tend to have a less prudent relationship with the risk than stabilized adults (Carbone, 2003). Conversely, elderly people are particularly worried and crystallized, as health and proximity to death put them in an anxious and rigid position compared to other cohorts (Lucidi, 2005).

- Direct control: psychological strategies related to risk perception and needs analysis are influenced by the degree of control exercised over events and threats. The less direct control over events, the greater will be the perception of risk and danger, the more bitter and rooted will be the strategies on the analysis of needs.

- Imitation and Association: sharing danger and threats allows for coping and emotional re-elaboration strategies. Imitation (let us do as others do) and association (together we will come out of it) encourage social cohesion and allow for the homologation of norms, rules, and practices. In this way, we can both overcome the crisis in practical terms and alleviate social anxiety and individual concern about the emergency.

Parents are guardians and co-builders of their children's evolutionary trajectories and feel responsible for the promotion and protection of their bio-psycho-physical well-being in all areas of life (ivi). 
A health emergency that affects all areas of social life necessarily becomes a space for parents to re-elaborate needs, priorities, and risks in the physical, psychological, social, and pedagogical spheres.

We can consider bio-psycho-social needs in the evolutionary age by dividing them into 4 main areas:

- Biological health and growth: health and physical well-being represent the main axis of the analysis of needs in developmental age. Nutrition, the general state of health, physical growth and the achievement of biological developmental stages represent the pivotal points of the process of parents' care and epimelesis towards their children.

- Emotivity: growth and emotional empowerment represent one of the main aspects of the evolutionary age. The development of emotional intelligence and the right emotional framework allows children to navigate world and build coherent and functional interpersonal relationships.

- Socialization: the development of social and relational skills is paramount for the evolutionary growth of children. In puberty and adolescence, socialization and relational processes are paramount for the process of needs analysis by parents the main educational figures.

- Didactics and learning processes: another important aspect in the evolutionary growth of children is represented by the complex interweaving formed by didactics and learning processes. From primary school to university entrance, the didactic and notionist training of children is an emotional and relational space in which the parent-children relationship can be expressed.

The school represents the first testing ground for children, in which to carry out an activity outside the family microsystem and give feedback to parents both in terms of performance and in terms of rewarding their children's expectations and imaginary constructions (Ligorio et al. 2006).

Inequalities and differences in educational processes: from social mobility to Digital Divide.

The COVID-19 emergency in Italy, with the lockdown, self-isolation and the suspension of productive, economic and relational activities during Phase 1, have highlighted the differences and social inequalities, especially in training processes, access to educational resources and the educational and evolutionary trajectories of individuals.

Social inequality, therefore, becomes evident when there is a systematic difference in the distribution of goods and privileges for certain individuals and social categories. 
The theme of inequality in educational processes assumes sociological value when education is configured as a need expressed, on the one hand, by the labour market and, on the other, by the need for mass literacy (Gallino, 1983; Schizzerotto, 1991).

Rovati (1992) defines two levels of social equality, both applied to education in sociological analysis:

- Equality in the possibilities of access, considered as the possibility, predisposed to all individuals in a community, to access positions of power and prestige.

- Substantial equality understood as the possibility of using the same means and enjoying the same rights as other individuals or social categories.

The vision of substantial and universal equality of individuals in social systems, also known as egalitarian optimism, is flawed when we consider the school universe. In it, conceptual approaches recognizing social inequalities and the different evolutionary trajectories of individuals find fertile and epistemological ground (Ammaturo, 2019).

Floud, Halsey e Martin (1956) and Douglas (1964) talked about cultural deprivation or deficit theory. They pointed out how young people from lower social classes tend to have worse school performances because families do not provide adequate tools and resources to ensure social equality and evolutionary trajectory. To name but a few examples: the purchase of books, multimedia supports, or enrolment in foreign language courses. Moreover, according to the authors, there is a tendency in poorer families to encourage the early entrance of young people into the labour market rather than pursuing higher education, which they see as an unsustainable family expense. Conversely, the youngster's entrance in the labour market would add to the family income.

The theories of social inequality are extremely topical in the analysis of the COVID-19 emergency when analysing the psychological, social and pedagogical aspects of the management and elaboration of the Distance Learning Experience (DL), a teaching and learning method made available by the schools to guarantee continuity to the 2019-2020 school year.

The social and instrumental differences of families to access technological and multimedia resources to guarantee DL to their children have been highlighted in several social research and pedagogical debates.

Based on this premise, there is a pedagogical and didactic digital divide between poorer families and those of higher social classes, and this aspect has weighed on the didactic continuity of the pupils and has also influenced the final evaluations and judgements of the school curriculum. 


\section{Methodology and data analysis}

Starting from the theoretical premises examined so far, the research aimed to analyse the psychological, social and educational aspects of parents with children in developmental age, during the lockdown aimed at preventing the spread of COVID-19 in Italy. We examined the so-called Phase 1 of the exceptional measures, from March 9 to May 4, 2020.

We examined, through separate research questions, parents' opinions on social distancing rules and the continuous and massive use of new technologies for Distance Learning.

We paid particular attention to the main emotions experienced by parents as well as those perceived by their children.

A final section addressed the main concerns of parents for the phase after lockdown, when Italy, in the autumn, is expected to return to a gradual restoration of social and educational activities, and learn to live with the virus (called Phase 2).

We administered an online structured questionnaire, subsequently expanded by indepth interviews with the parents. The semi-structured interviews considered the following sub-dimensions:

- Perception of health risks: concerns about contagion, the characteristics of the virus and the disease, the characteristics of vulnerable individuals considered at higher risk.

- Emotions and psychological aspects: moods, emotions, sensations, and elements related to emotional evolution during Phase 1.

- Online sociality vs. Offline sociality: opinions, perceptions, concerns about the massive daily exposure to new technologies and social media and its influence on face-to-face socialization.

- Didactic continuity: opinions, perceptions and concerns about the measures implemented to ensure teaching continuity during Phase 1 , influences on the evolutionary and didactic line of children/youngsters, and opinions about measures and strategies for Phase 2.

- Concerns for Phase 2: opinions, perceptions, concerns, and reflections, for themselves and their children, for when they will progressively return to everyday life while maintaining safety and social distancing rules to prevent the spread of contagion.

The research involved 150 parents between 30 and 55 years old, married and/ or divorced, resident in the Regions of Lombardy, Emilia-Romagna, Lazio, Marche, Abruzzo, and Campania, with children between 3 and 18 years old. 
The participants were selected using a stratified sampling methodology based on specific parameters. We considered the following criteria: family structure, distinguishing between families with both coresident partners and families with noncoresident partners (e.g. in case of separation), residence and type of children (preschoolers, school age, teenagers, etc.).

To take into account the various perceptions and concerns of the parents interviewed, we created separate reference groups according to their residence, related to the regional epidemic data. We considered as the discriminatory parameter the percentage of cases reported nationally as of March 30, 2020, date identified as the epidemic peak by the Istituto Superiore di Sanità ${ }^{1}$.

We identified 3 reference groups:

- High Exposure: including the regions of Lombardy (44.7\% of national cases) and Emilia-Romagna (13.9\%).

- Medium Exposure: including residents in Marche (3.8\%) and Lazio (2.9\%).

- Low Exposure: including parents living in Campania (1.4\%) and Abruzzo (1.4\%).

The number of parents per group is balanced: $30 \% \mathrm{HE}, 30 \%$ in $\mathrm{ME}, 40 \%$ in LE.

\section{Parents' views on the health sector}

The analysis showed how the epidemic data and the news on the evolution of the disease during quarantine have oriented the perceptions of risks in the health sector also depending on the reference area.

\footnotetext{
${ }^{1}$ COVID-19 was identified in December 2019 in Wuhan, China. In the second half of February 2020 the SARS-COV2 virus spread to several continents, including Europe, forcing the WHO on 11 March 2020 to declare a pandemic.

In Italy, the regions of Lombardy, Veneto, Emilia Romagna were declared a red zone at the end of February 2020 and major measures were implemented to contain the contagion, avoiding a collapse of the local health system.

On March 9, 2020, the Italian Government extended the red zone to the entire national territory, imposing social distancing, shelter-in-place orders and the full closure of all working, commercial and relational activities until May 4, 2020.

From May 4 to June 3, 2020, Italy has entered Phase 2, with the gradual resumption of commercial and working activities and the possibility of citizens moving around the national territory, maintaining health regulations and social distancing.

On June 3, 2020, while moving to Phase 3 , Italy counts 233,836 cases and 33,601 deaths, of which more than $40 \%$ in the Lombardy region.
} 


\begin{tabular}{|l|l|l|l|}
\hline Healthcare Area & High Exposure & Medium Exposure & Low Exposure \\
\hline $\begin{array}{l}\text { High-risk subjects } \\
\text { (older adults, cancer } \\
\text { patients, people with } \\
\text { underlying medical } \\
\text { conditions) }\end{array}$ & $50 \%$ & $33 \%$ & $56 \%$ \\
\hline $\begin{array}{l}\text { Family (spouse and } \\
\text { children) }\end{array}$ & $50 \%$ & $67 \%$ & $33 \%$ \\
\hline $\begin{array}{l}\text { Characteristics of the } \\
\text { virus and the disease }\end{array}$ & -- & -- & $11 \%$ \\
\hline
\end{tabular}

Table 1. Parents' opinions on the Healthcare Sector

Table 1 shows that $52 \%$ of the respondents fear contagion for their loved ones and children, with a lower percentage for parents living in Campania and Abruzzo, regions where there were no real internal outbreaks, but only cases "imported from other regions".

If we divide the data by area, in High Exposure regions, such as Lombardy, the perception of risks is hyper-extended to all areas of everyday life (work, family, society) due to the severe epidemic data and perceived inadequacy of the public health system. Parents living in Emilia-Romagna have greater peace of mind because they are supported by a health system considered the best in the country. This data is interesting because it would confirm the studies pinpointing the social organization and the Welfare State as important instruments of mediation in the perception of global risk (Back, 2006; Galatini, 2010).

I live in a city where, thank God, the health care system works very well and even though there was a major emergency in March, I have never felt in danger. I've always thought: if it goes wrong, l'll still be admitted to one of the best hospitals, so I've never been so worried. (Chiara, 42, Bologna)

The perception of risks in the health sector is different for the Regions in the Medium Exposure and Low Exposure areas.

Parents in Lazio perceive the emergency as "something to avoid" and not worryingly present in the territory, trusting in the prevention offered by the security measures and social distancing. For parents living in Marche and Abruzzo, the fear of Covid-19 contagion derives mainly from the health system itself, as the greatest spread of the virus in these regions occurred in hospitals and health care facilities, highlighting the precariousness of a system that should protect and reassure citizens. 
I am afraid I will have to go to a hospitla, because here in Teramo all the cases have come from Mazzini [hospital]. I mean, how can a person go to the hospital to cure something and catch a deadly virus? (Angela, 47, Teramo)

For parents living in Campania, the greatest danger lies in the invasion from the North, since for them the virus was "carried" by people living in the North who reached the South before the definitive restrictions of the Prime Ministerial Decree of 9 March 2020. This behaviour was considered by many as lacking in civic sense and showing "little respect for their land and their families of origin", confirming, on the imaginary level, the classic contrast in Italian society between North and South.

The real problem will be if the Regions reopen because most of the cases here in Campania are parents, grandparents, and relatives of people from the South who work in the North. You have to close everything, don't wait for these reckless people to come here, it's not love for your family and your land! (Matteo, 47, Salerno)

High-risk categories (elderly, cancer patients and immunocompromised patients) represent the main concern for $42 \%$ of the interviewees. This percentage corresponds to the part of the sample with greater attention to epidemic data and information from the scientific community on the characteristics of the virus, scientific discoveries and increased anxiety management through information and updating.

\section{Emotions experienced and concerns related to psychological aspects}

The analysis of the questionnaire and the interviews showed that the main emotion experienced by parents during lockdown was Fear (78\% of the interviewees), homogenously distributed among the groups. The second emotion experienced is Anxiety (63\% of the cases), followed by Anger (33\%), Disorientation (21\%) and Resignation (21\%).

\begin{tabular}{|l|l|l|l|}
\hline $\begin{array}{l}\text { Emotions and psychological } \\
\text { aspects }\end{array}$ & High Exposure & Medium Exposure & Low Exposure \\
\hline Fear & $70 \%$ & $75 \%$ & $65 \%$ \\
\hline Anxiety & $65 \%$ & $60 \%$ & $65 \%$ \\
\hline Disorientation & $50 \%$ & $15 \%$ & $45 \%$ \\
\hline Anger & $45 \%$ & $35 \%$ & $55 \%$ \\
\hline Resignation & -- & $12 \%$ & $15 \%$ \\
\hline
\end{tabular}

Table 2. Emotions and psychological aspects

So much stress for parents to deal with, [about] work, with the fear of going to work and bring the virus home to their loved ones. (Mario, 41, Brescia) 
It is interesting to note a difference between the emotions experienced by parents and children. While for parents the emotional fear/anxiety combination emerges in almost all the respondents, the predominant emotion for children (perceived and reported by the parents) during the quarantine varies according to their age and the pedagogical and educational strategies implemented by the parents.

Specifically, children between 3 and 5 years mainly showed irritability and frustration (75\% of cases), pre-adolescents and adolescents experienced boredom (55\%) and in some cases positive emotions such as serenity due to the comfort situation (no school, performance requirements, or scheduling for school and extracurricular educational activities).

The interviews showed that everyday life pre-Covid19 followed a structured agenda with clear, organized, and replicable rhythms. The lockdown altered or even annulled the previous organizational structure, forcing families to re-negotiate the relational dynamics and educational priorities, destabilizing especially the youngest children, still unable to discern the external reality.

Conversely, pre-adolescents and adolescents, being able to analyse more analytically the information coming from the environment, have been able to build themselves autonomously, highlighting their resilience by drawing on technological resources and a greater media expertise, as well as ideas and possibilities for socialization and entertainment.

The fundamental role of the pedagogical and social opportunities provided by the adults of reference (parents and educational figures) also emerges. Boredom and frustration were experienced by children/youngsters with pedagogical deficiencies (parents' working conditions suspended, school not yet equipped enough for distance learning) or not able to access the technology needed (Digital Divide).

Much better than ours. I saw on their side a capacity to adapt to this situation, seen much more peacefully than my husband and my parents. The fact of living relationships over the phone with calls, which my children did not do before, made them live social distancing better than me, because I have a different approach to virtual relationships. (Emanuela, 52, Rome)

The child is quite serene because we try not to make the situation weigh too much on her, by always organizing something, taking her to the garden, inventing activities, filling her days with a new routine! (Daniela, 42, Teramo)

\section{Online sociality vs. Offline sociality.}

As regards the perception of risks due to the use of social media and online socialization to the detriment of face-to-face socialization skills, the results are reported in Table 3: 


\begin{tabular}{|l|l|l|l|}
\hline $\begin{array}{l}\text { Online Sociality vs. } \\
\text { Offline Sociality }\end{array}$ & High Exposure & Medium Exposure & Low Exposure \\
\hline Negative Outcomes & $50 \%$ & $50 \%$ & $60 \%$ \\
\hline Positive Outcomes & -- & $25 \%$ & $33 \%$ \\
\hline $\begin{array}{l}\text { Adaptability of digital } \\
\text { natives }\end{array}$ & $50 \%$ & $25 \%$ & -- \\
\hline $\begin{array}{l}\text { Rejection for technology } \\
\text { and social networks after } \\
\text { Covid-19 }\end{array}$ & -- & -- & $16 \%$ \\
\hline
\end{tabular}

Table 3. Online sociality vs. Offline sociality

The data show that for $57 \%$ of respondents the massive use of technology during the Covid-19 emergency can affect and exacerbate dysfunctional behaviour already manifested before the Coronavirus emergency. In online socialization. Children, especially adolescents, can find relational comfort consolidating social phenomena such as Hikikomori (Bagnato 2017, Ricci 2009) and Neet.

I believe that children are affected; before they were used to have a full day on all fronts, school, homework, soccer, dancing and they always had something to fill their day, they socialized with other children. Now I see that many times they look at me and say: what are we going to do today? Who can I talk to? The main damage to children is in socialisation. (Giovanni, 32, Bergamo).

$21 \%$ of the interviewees, instead, consider the use of social media and technology an obligatory and functional passage, hoping to maintain it even when the Covid-19 emergency will be over, both in terms of remote working for adults and as an alternative to in-person teaching.

Interestingly, $21 \%$ of the interviewees consider the "social media and technology issue" as a concern only for analogue natives. For the new generations, called "digital natives", there is no big difference between online and offline socialization, these being two extremes of a continuum of a relational and social offer - in line with Rogers' theories (2016) on the gradual disappearance of cyberspace and the emergence of multidimensional social contexts.

I do not think they will have any difficulties. My eldest son uses socials a lot, he has friends all over Italy, so they didn't see each other much before and consequently there is not all this need to see each other. Let's say that they managed it better, I miss my friends more. (Viviana, 34, Rieti)

Finally, for $1 \%$ of the interviewees, the exclusive use of online socialization will lead to a rejection towards technologies in the immediate post-quarantine phase due to the natural propensity of human beings towards face-to-face socialization 
As McLuhan (1967) maintained, the media are not mere information channels, but they can also shape thoughts and thinking processes. For Carr (2010), the net shatters any capacity for concentration and contemplation with the risk that it may lead to obsolescence of the capacities and scripts typical of face-to-face socialization.

\subsection{Educational and didactic aspects}

School and education are an important source of concern for parents on the future development of their children.

Uncertainty about the epidemic progression, the continuous postponement of schools reopenings, the absence of in-presence teaching and the transition to Distance Learning (DL) for the school year 2019-2020, had a decisive influence on both the judgement and the perception of the effectiveness of the measures adopted by the Ministry of Education during Phase 1.

\begin{tabular}{|l|l|l|l|}
\hline $\begin{array}{l}\text { Didactic and } \\
\text { pedagocical paths }\end{array}$ & High Exposure & Medium Exposure & Low Exposure \\
\hline $\begin{array}{l}\text { Organisational } \\
\text { deficiency }\end{array}$ & $75 \%$ & $25 \%$ & $30 \%$ \\
\hline $\begin{array}{l}\text { Negative impact on } \\
\text { well-being }\end{array}$ & -- & $25 \%$ & $55 \%$ \\
\hline Digital divide & $25 \%$ & -- & $10 \%$ \\
\hline $\begin{array}{l}\text { Guaranteed teaching } \\
\text { continuity }\end{array}$ & -- & $50 \%$ & $5 \%$ \\
\hline
\end{tabular}

Table 4. Educational and didactic aspects

For $31 \%$ of the respondents, both the Ministry and the school system lacked organisation. This perception is very evident in the High Exposure area (75\%), where the emergency began three weeks before the Prime Ministerial Decree of 4 March 2020, effectively lengthening the pupils' absence from traditional teaching. Moreover, the interviewees point to organizational discrepancies among the very tools implemented by the institutions, causing frustration for parents who had to learn new support procedures for their children in a short time.

Yes, then there is also the school problem. No two schools have the same type of homework, for example, they use different platforms, so each platform has a different way of working for each class. One class works on Skype, another one uses another program, and keeping track of the various issues in each program is tough. (Antonella, 41, Piacenza).

$25 \%$ of the respondents accuse organizational shortcomings and disparities even among school levels, denouncing a pedagogical abandonment for pre-school, primary school, and at-risk categories. 
As far as the girl is concerned, the school chose not to do distance education with primary school children. At first, I thought it was a good choice, but going forward and seeing that this would continue throughout the year the children started to suffer from it. So, we talked it over with the teachers who will do three meetings a week for an hour. Of course, it is not distance learning, but the children have a contact with a figure that is important for them at a relationship level, so much so that the video lessons will not focus on teaching but on the relationship and contact with the children. (Martina, 36, Latina)

$7 \%$ of the interviewees highlight the issue of the digital divide. Some parents underline how the Covid-19 emergency has "brought to the surface" inequalities and social inequalities already consolidated in our society. Online distance education is possible for some social categories and social classes, while for "fragile" categories (e.g. socioeconomic discomfort, learning difficulties, immigrants, etc.) it becomes off-limits, increasing the learning gap already present in face-to-face teaching.

There have been some discrepancies because, as in my case, I have received messages from children who do not have a computer or do not have a suitable connection, and so these children trust the figure of the educator with these concerns, they ask for help and so they discover another world. For distance learning I know that they are taking steps to deliver tablets with an internet connection, I was tempted to ask for it for my son but in the end I didn't ask for it thinking that it could be useful to someone else. Distance learning is for rich people! (Kikka, 34, Salerno)

$36 \%$ of respondents have a positive perception of $\mathrm{DL}$ and the measures taken for educational continuity. However, it is important to analyse the data relating to the three sub-groups: $50 \%$ of the respondents from the regions of Lazio and Marche expressed a positive opinion on $\mathrm{DL}$, compared to only $5 \%$ of the respondents from Campania and Abruzzo, a negative opinion for the parents from Lombardy and EmiliaRomagna.

This data is, therefore, very location-related and influenced by the individual responses of the schools and not as a trend that can be generalized to all regions.

The school year 2019-20 will weigh negatively on the evolutionary and didactic trajectory of the children/youngsters for $65 \%$ of the interviewees, while for $30 \%$ the cognitive plasticity of the pupils will be able to recover when they will return to in-presence teaching and face-to-face relationships.

Concerning the projections on the school year 2020-2021, when Italy will presumably be in Phase 2, 35\% of respondents support delaying the beginning of the school year until the emergency will be over or a vaccine against the virus will be announced, considering DL a measure "to play for time" not to be adopted in the long term. 
$29 \%$ of the respondent is in favour of continuing $D L$ for the first phase of the new school year, considering it unsafe to return to the classroom but not sustainable the total suspension of teaching and learning processes until the end of the emergency. This position stems from a painful negotiation between two types of anxiety: on the one hand, the fear of the virus and the disease not yet curbed, on the other the concern for the educational and evolutionary process of their children.

$36 \%$ of the interviewees are in favour of returning to school with social distancing, as they consider DL ineffective and the contribution of face-to-face relationships to the learning process to be fundamental. When reopening schools, they would implement strict and rigorous rules for the prevention of contagion.

\section{Phase 2: Fears and hopes}

On May 4, 2020, the Italian Government promulgated a series of Decrees that phased the reintroduction of the relational, social and economic activities of the country, maintaining strict and rigorous safety protocols (sanitization measures, use of masks and gloves) and social distancing (physical distance in interpersonal relations), commonly referred to as Phase 2.

In the interview, carried out during Phase 1, participants were asked to identify their main concerns and fears concerning the new phase, which will necessarily involve living with the virus. The data are shown in Table 5:

\begin{tabular}{|l|l|l|l|}
\hline Concerns and fears for Phase 2 & High Exposure & Medium Exposure & Low Exposure \\
\hline School and education & $45 \%$ & $25 \%$ & $35 \%$ \\
\hline Economy and social instability & $75 \%$ & $75 \%$ & \\
\hline $\begin{array}{l}\text { Second wave of the pandemic } \\
\text { and virus mutation }\end{array}$ & $35 \%$ & $15 \%$ & $35 \%$ \\
\hline $\begin{array}{l}\text { Compliance with safety and } \\
\text { social distancing rules }\end{array}$ & $75 \%$ & $70 \%$ & $75 \%$ \\
\hline
\end{tabular}

Table 5. Concerns for Phase 2

Each respondent expressed at least two concerns related to Phase 2: 75\% worry about the lockdown-induced economic crisis and its repercussions on the social stability of the country, while $5 \%$ mention scepticism towards people's compliance with safety and social distancing rules.

Didactics and school (35\%) represent one of the parent's main concerns about their children for Phase 2: complying with safety regulations, social distancing and the fear of a second wave (25\%) after the summer all consolidate feelings such as anxiety, uncertainty and fear. 
I am sure there will be a second wave, my feeling is that we will have to learn to live with the virus, as we did with past influences. We will certainly have to change our habits and the thing that worries me the most is the distance that all this will lead us to have less confidence for others. (Daniela, 39, Parma)

\section{Conclusions}

The COVID-19 emergency and its period of quarantine and social distancing represented a social event of unprecedented global significance in recent history, forcing individuals to rework and reorganize social reality as they knew it.

There has been a radical change in organisational structures and practices, channelling all human activities into a common and overarching objective: to avoid health, social and economic collapse.

As the social world shrank and all human activities were suspended, the family microsystem (the house) became the new space for reorganization, supported by technology and digitalization.

The house became the safe place, it took on the connotation of a macro-place from where one could continue to be oneself in all areas of life, from work to teaching, from socialization to leisure time.

In this new conception of daily life, housebound but safe from contagion, parents had to, on the one hand, reorganize their working life and, on the other, respond to the analysis of their children's evolutionary needs, without neglecting the emotional and psychological aspects related to a difficult situation and without a semantic anchorage in the collective memory.

Our results show that the main concerns of Italian parents were directed towards two main aspects: on the one hand, the emergency in terms of health and health-related aspects; on the other hand, the didactics, training and educational trajectory of their children. They showed distrust and scepticism towards institutions and the school world in terms of both management competence and structural and infrastructural capacity, aspects perceived as concerns also for Phases 2 and 3 of the epidemic curve.

Finally, parents' stories highlight the feeling that distance education has further emphasized and exacerbated social differences and inequalities, underlining the presence of a pedagogical and didactic digital divide in all levels of education and areas of Italy included in the research.

The developments of this research can be manifold. It would be interesting to analyse the perception of social risk and the presence of the pedagogical and didactic digital 
divide with a greater historical distance from the emergency, to grasp aspects not influenced by psychological and emotional aspects derived from the "proximity to danger" and to investigate the social and pedagogical aspects stabilized and conceptualized, to apply also in social and didactic planning.

\section{Bibliography}

1. Ammaturo, N. (2019), Etica e Educazione. Vie d'uscita da una società immorale. Aracne, Roma.

2. Bagnato, K. (2017), L'hikikomori: un fenomeno di autoreclusione giovanile. Carrocci Editore, Roma.

3. Ballhysa, Narbis, and Marita Flagler. "A teachers' perspective of inclusive education for students with special needs in a model demonstration project." Academicus 3 (2011): 121.

4. Beck, U. (2000), La società del rischio. Verso una seconda modernità (W. Privitera, Trad., 1. ed.). Carocci, Roma.

5. Beck, U. (2006), Living in the world risk society. Economy and Society, 35 (3), 329-345. https://doi.org/10.1080/03085140600844902

6. Beck, U. (2008), Conditio humana. Il rischio nell'etá globale, Laterza, Bari.

7. Binotto, M., \& Cerase, A., \& Di Stefano, A., \& Liuccio, M. (2011), La malasanità in scena. Anatomia di un "caso mediale". Edizioni Nuova Cultura, Roma.

8. Carbone, P. (2003), Le ali di Icaro. Rischio ed incidenti in adolescenza. Bollati Boringhieri, Torino.

9. Carr, N. G. (2010), Internet ci rende stupidi? (S. Garassini, Trad.) Raffaello Cortina Editore, Milano.

10. Castells, M. (1996), The Rise of the Network Society, The Information Age: Economy, Society and Culture, Vol. I. Cambridge, MA; Oxford, UK. Blackwell.

11. Çalişkan, Nilüfer, and Akida Mulgeci. "Waste identification lean approach in effective education system-case of Albania." Academicus 12 (2015): 199.

12. Davids, M.F. (2020), L'islamfobia, Franco Angeli, Milano.

13. Douglas, J. W. B. (1964), The Home and the School. A study of ability and attainment in the primary schools. Macgibbon \& Kee, United Kingdom.

14. Douglas, M., \& Wildavsky A. (1982), Risk and Culture: An essay on the selection of Technical and Environmental Dangers. University of California Press, Berkeley.

15. Douglas, M. (1991), Come percepiamo il pericolo. Antropologia del rischio, Feltrinelli, Milano. 
16. Floud, J. E., \& Halsey, A. H., \& Martin, F. M. (1956), Social Class and Educational Opportunity. London: Heinemann.

17. Galantini, M. G. (2010), La società della sicurezza. La costruzione sociale della sicurezza in condizioni di emergenza. Franco Angeli, Milano.

18. Gallino, L. (1983), Personalità ed industrializzazione. Loescher, Torino.

19. Giddens, A. (1994), Le conseguenze della modernità. Fiducia e rischio, sicurezza e pericolo (M. Guani, Trad., 1. ed). II Mulino, Bologna..

20. Iovan, Marţian. "Eco-education: A required element of public policies for sustainable social and economic development." Academicus International Scientific Journal 09 (2014): 14-28. Joffe, H., \& Bettega, N. (2003), Social Representation of AIDS among Zambian Adolescents. In Journal of Health Psychology, 8, pp. 616-631.

21. Joung, B. (2002), L'assistenza psicologica nelle emergenze. Erickson, Trento.

22. Ligorio, M. B., \& Cacciamani, S., \& Cesareni, D. (2006), Blended learning. Dalla scuola dell'obbligo alla formazione adulta. Carocci, Roma.

23. Lucidi, F., \& Grano, C. (2005), Psicologia dell'invecchiamento e promozione della salute. Carocci, Roma.

24. Lupton, D. (2003), II rischio. Percezioni, simboli, culture. II Mulino. Bologna.

25. McLuhan, M. (1967), Gli strumenti del comunicare, II Saggiatore, Milano.

26. Pitrelli, N., \& Sturloni, G., (2007), a cura di, Atti del V Convegno nazionale sulla comunicazione della scienza. Polimetrica, Roma.

27. Ricci, C. (2009), Hikikomori. Narrazioni da una porta chiusa. Aracne, Roma.

28. Robo, Marsela. "Social inclusion and inclusive education." Academicus International Scientific Journal 10 (2014): 181-191.

29. Rogers, R. A., \& Severo, M. (Cur.). (2016), Metodi digitali. Fare ricerca sociale con il web (V. Partesotti, Trad., 1. ed.). II Mulino, Bologna.

30. Rovati, G. (1992), Uguali e diversi. Il problema della stratificazione sociale. Vita e Pensiero, Roma.

31. Schizzerotto, A., (a cura di) (1991), Classi sociali e società contemporanea. Franco Angeli, Milano.

32. Slovic, P. (2000), Risk, society, and policy series. The perception of risk, Earthscan Publications.

33. Sontang, S. (1989), L'Aids e le sue metafore, (C. Novella, Trad.). Collana Nuovo Politecnico n.166, Einaudi, Torino; poi in Malattia come metafora: aids e cancro. Einaudi, Torino, 1992 e Mondadori, Milano, 2002. 